\title{
The Anti-War Movement through Romanticism of the Hippie Culture on Vietnam War 1965-1973
}

\author{
Dwi M. Nugroho, Muhammad J.B. Firdaus, dan \\ Adam J. Wijaya \\ Universitas Pembangunan Nasional "Veteran" Jawa Timur
}

\begin{abstract}
In this paper, the authors try to provide an overview of the new social movement variant, which is the anti-war movements initiated by hippies. The hippie culture developed rapidly in the 1960s in the United States and now has spread to the whole world through cultural globalization. Hippie Movement itself is a subculture movement that has a significant role in forming a counter-culture in the United States. This movement's success cannot be separated from the support of the musicians of the world through popular culture that will be discussed in this paper through cultural globalization.
\end{abstract}

Keywords: anti-war movements; globalization; hippie; USA; new social movements

Tulisan ini memberikan gambaran tentang varian gerakan sosial baru, berupa gerakan anti perang yang digagas oleh kaum hippies. Budaya hippie berkembang pesat pada tahun 1960-an di Amerika Serikat dan saat ini telah menyebar ke seluruh dunia melalui proses globalisasi kultural. Gerakan Hippie itu sendiri merupakan salah satu gerakan subkultur yang memiliki peran signifikan dalam counter-culture di Amerika Serikat. Keberhasilan gerakan ini tidak lepas dari dukungan para musisi dunia melalui budaya populer yang dibahas dalam tulisan ini melalui globalisasi budaya.

Kata-kata Kunci: anti-war movements; globalisasi; hippie; Amerika Serikat; gerakan sosial baru 
The United States of America organically is a place of criticism towards state hegemony, mainly by assessing its gestures and actions to the international system. In this contemporary era, the condition of every state has grown along with the rapid movement of globalization. As a consequence, it is important for International Relations scholars to comprehensively look into the effect of globalization on the order of society. Antonio Gramsci's work on Cultural Hegemony extensively explains how in a maturing era civil society has a role and position of bargaining to the public control state hegemon.

Cultural hegemony is a notion which explains the manipulation of a society's culture by a ruling class, which indicates the ruling class views as the accepted cultural norm. Gramsci noted that this hegemony is attainable by acquiring the consensus of the society through leadership and persuasion (Buttgieg 2005, p. 38). Cultural hegemony has influenced the birth of activist politics of socially liberal and progressive politicians. Civil society, more or less, is an ensemble of popular progressive oppositional movements not formally or necessarily affiliated with a specific political party (Buttgieg 2005, p. 34). Globalization and the rise of civil societies have increased the value and influence of these movements to the social structure in a global landscape, seeing that state hegemony is constantly being reinforced.

One notable example of the influence of civil society in a global landscape is the rise of the Hippie Culture during the Vietnam War period. The "Hippies" is a group of people whose identity revolves around being a part of the Flower Generation. The Flower Generation comes from the phrase "fight with flower", this term is inseparable from the ideology they carry, namely non-violence and love for peace in the anti-war movement. The slogan that were used during the movement was "Make Love, Not War ". The ideology of this movement continues to be a complex term often used to isolate leftist parties or groups. This paper seeks to comprehensively review how the anti-war movement initiated by the Hippies in forming counter culture has succeeded in reducing the aggressiveness of US foreign policy regarding Vietnam's war policies and its impact on global politics.

One interesting fact about this movement is that it was channeled through artwork, especially through a media of music, in which it has the support of great musicians such as Jimi Hendrix, Janis Joplin, John Lennon, and other great musicians in developing, supporting, participating as an activist on anti-war issues and violence. This 
is mainly due to the fact that listening to rock or country music is one of their main traits. Art itself was chosen as the first step in the movement of hippies not without a cause; Art is used as a mouthpiece of the movement, because it offers an alternative that meets the saturation of post-war society. We, the authors, think that art does not only stop at the level of "medium" but has a central role as a gathering of networking, propaganda, and agitation for the hippie's movement. Ron Eyerman (2002, p. 447) states that music and other forms of cultural expression can articulate a group by offering a sense of group belonging and strength in trying situations. By that statement, we can draw the understanding that art can be used as political mediators from the voice of the people.

\section{Methodology}

The type of research that we intend to use is the analytic descriptive type, that is, research that uses a pattern of describing the state of empirical facts along with relevant arguments based on solid theoretical studies so that the results of the description are then followed by an analysis that results in analytic conclusions. After that, we will give the basic conceptual frameworks that help our analysis, before beginning into findings and discussions.

\section{New Social Movements}

In its development, the form of social movements is divided into two, which are the old social movements and new social movements. Old social movements, also often referred to conventional social movements, are movements that are tend to be based on economic aspects or aspects that lead to the high political approach, along with the dynamics of global politics and their significance. New social movements exist to complement the paradigm of old social movements, often referring to themes that are more flexible. New social movements focuses its basic aspects on matters that were not yet of significant concern at the previous moment, for example are security issues that directly targets the community (i.e., food security, health, environmental security, personal, political, and community security). It differs from cases of significant concern to the conventional social movements which focuses on the alienation of workers, where the economy is a major problem in the formation of a framework of conflicted relations in a social movement.

In this paper, we attempt to dissect the case using the new form of social movement. Steven M. Buechler (1995, p. 441) stated that there are skepticism regarding the influence new social movements 
may bring on understanding movements. It is further elaborated that new social movements emphasize the attempt to create space to further understand social movements, therefore allowing intellectuals to reach alternative approaches. One alternate example is social constructionism, which brings symbols to the study of collective action by emphasizing the role of activities and bringing the process of cultural work to social activism (Buechler 1995, p. 441). This indicates that through the New Social Movements Theory, contemporary social movements are possible to be studied through scientific and empirical studies. The existence of flexibility as a force for new social movements can be observed when social movements tend to originate from elementary aspects in communal life such as identity, health, culture, education, and much more.

\section{Mass Communication}

Mass communication primarily refers to the form of delivery of substance, which then will be conveyed by the transmitter to the target party. It is safe to assume that mass communication encompasses unidirectional relations, because a message from a party could be simultaneously consumed by many recipients. Unidirectional relationship means message flows only in one direction, therefore it triggers triggers the formation of space and its mass to expand in relatively flexible time, depending on the progression of the mass shelter within the movement.

The development of the flow of information becomes an aspect that is related to one another, the existence of contemporary communication media enables the spread of communication itself to run in two directions, at any level of the structure, wherever without mediation or representation (Castells 2010, p. 406). Communications, both direct and mediated, in social movements are part of a tool of resource mobilization as well as the structure of interaction with external groups (Donk, et. al. 2004, p. 7-8).

Communication plays an important role in the widespread dissatisfaction, which then will lead into a social movement. Social movements do not bring the individuals behind them spontaneously and in a short time, but through a long process and decomposition. Individuals or groups who share similar experiences with one and the other then find that they have the same fate with other individuals or groups then will conduct a social movement. As a result, it proves that the process of learning requires communication and information exchange are both an important factor to social movement. It is also 
important to note that maintenance and changes in social orders both require communication (Das 1981, p. 130).

The mass, in this case, is not limited to a group of people, groups, and communities. It is more than that, the mass, is considered as a party with a massive quantity and is widespread. The masses are considered as parties who are less aware of self-awareness and the identity of themselves or groups, the masses are described as flexible and not linked or affiliated with any party, but are unable to move collectively (McQuail 2010, p. 107). The mass in this context is also described as a society that cannot be measured in terms of the quantity given the erratic structure and boundaries of the place of origin also cannot be determined, the high heterogeneity of the 'mass' this ultimately has high flexibility.

The mass is then possible to have a high probability to move militantly if the objects of concern that arise then represent collectively. In short, when the masses find one party who can influence and is considered to represent their identity (both symbolically and substantially), then it will be possible for the party to influence the mass. Although, it cannot be considered able to uniformly respond to the masses briefly, though at least mass communication is more controlling the mass in the face of a social phenomenon that occurs.

\section{Cultural Globalization}

The growing development of globalization is inseparable from the concept of interdependence in global politics. This has led to the globalization product called the global culture brought by the cosmopolitan. Cultural globalization is the substance of cosmopolitan discussions that often regulate discourse about global culture. It has been proven ever since Immanuel Kant wrote the Idea for a Universal History From a Cosmopolitan Point of View in 1784; global problems have been framed by universal and cosmopolitan terms (Poster 2008, p. 686). In its development, the cultural globalization was fragmented into three main views.

David Held, Anthony McGrew, David Goldblatt, and Jonathan Perraton (1999, p. 3-9) explains the three main views of cultural globalization, which are hyper-globalist, skeptical, and transformationalist. First, is hyperglobalist, they argue that the world will be homogenized into the same culture, dominated by Western culture. Second, is a skeptical view, they argue that global culture has very little influence on the local culture of each country. Third, is the transformationalist view, they argue that hybrid culture 
and new global culture will be created through the mixing of cultures due to the process of globalization. In the this case, hippie culture is present as a form of confirmation of the transformationalist view, where it can be seen from its development. Hippie culture in the United States is the center of its development despite the reality that the hippie's movement targets in other countries are different, because hippies in the United States are in sharp contrast to hippies in the Soviet Union.

Internal problems in the Soviet Union became a spark that ignites the fire of the movement. It could be said that Soviet hippies were a marker of the existential problems due to the decline of the Brezhnev era and the heavy grip on creativity (Manaev \& O'Callaghan 2018). However, it should be seen that the success of this movement in providing a paradigm of resistance to the selfishness of the state, an important medium that could not be separated through music. This makes the tendency of the writer that the cultural globalization through music becomes a movement that is developing throughout the world. Music and art can serve as a basis for recruitment and support, because through music a collective movement can make itself visible to others and establish a sense of continuity (Eyerman 2002, p. 447).

\section{Findings and Discussions}

Hippies in the United States are present as a form of counter-culture. It manifested through romantic social movements in the late 6os to early 70s, inhabited by teenagers and people in their early twenties through their flamboyant lifestyle revealed their alienation from America's lifestyle (Miller 1991, p. xvi). In 1968, Maloney (1968, in Miler 1991, p. xix) described the social structure in the United States as divided into three major generations: under 30, 30-45, and more than 45 of age. The majority of generations of the age 30-45 are children who experienced the Depression, which usually never cared too much about human values.

However, this revelation gives a different reflection on seeing the country. Maloney saw an impasse between the "young" and the "old" in the context of hope for the state as a guarantor and stated that indeed these things accentuate the need for a revolution. The revolution comes in a form of counterculture from the subculture in the United States of America. This movement is massive in its development by targeting the critics towards consumerism and creating a new agenda on humanity in the US foreign policy, 
particularly in the case of Vietnam War. This movement reached its peak of expression in the Anti-Vietnam War movement. The protesters criticized the country's selfishness to pursue hegemony in international politics by considering it to be «playing with force". The movement made an attempt to be heard and seen against the mighty strength of American military power (Macfarlane 2007, p. 34).

The hippie culture, which emerged in the late 1960 s and grew to the hundreds of thousands of young Americans across the country reached its peak during a period of increased American involvement in the Vietnam War and subsided as the conflict approach (Pruitt 2007). The Hippies shows its disagreement towards the American mainstream culture through their rebellion, their long hair and beard lifestyles, colorful styles, use of psychedelic drugs, love of rock music, and lifestyle conscious of environmental issues.

While having fun with music, LSD, and sex, the young generation, the Flower Generation regularly held anti-war protests. One of the famous anti-war parades is the one held on October 21st, 1967. The hippies took the street wearing hippie's clothes as they headed for the Pentagon and of course, confronted by soldiers complete with guns and bayonets. Nevertheless, there was no violence, because the flower generation is a group of young pacifists (Wibisono 2017). They instead shoved flowers at the soldier. The attempt to self-destruct and love self-freedom without rules from the state is a criticism for the hippies for their anger towards the country, which is throwing away state funds for the needs of war.

Conscription certainly led to mass killings on the battlefield. The tendency of the discussion of Hippies in this writing, especially in the field of music, music is a medium of mass communication. This made an important concern in the perpetuation of this movement. The essence of music has a noble agenda as a medium for delivering messages to be directed in the direction of many audiences. Music is also a part of the artwork, regardless of its quality; it has completed its task as a time-freezing media and everything in it, because it establishes the sense of continuity (Eyerman 2002, p. 447).

The existence of music can be translated through different interpretations of each individual. Moreover, the supported media by the music industry makes the value of music more easily conveyed to the public. This is evidence that the development of this movement is supported and sought after by many young people in the United 
States is a threat to the country, because of its ability to fuse a group (Eyerman 2002, p. 447). The hippies in the security and peace campaign are very much at odds with the state, which only focuses on the existence of an international forum by ignoring the people's rights, which are carried out as state obligations.

\section{Political Agenda}

Existence of the Anti-War movement of the hippie culture, notably in the form of a utopian ideal of the world that is free of war. Therefore, giving an understanding that this ideal cannot be separated from the cosmopolitan thinking. Discussing cosmopolitanism, in essence, is often related to the views of an entity regarding the form of ways individuals can mingle with one another by respecting differences. The word cosmopolitan is derived from the Greek word "cosmos" which means the world and "polis" meaning city. If interpreted, we can conclude that cosmopolitanism refers to an understanding for citizen of the world, also often referred to as global citizen.

The Stoics originally brought this understanding of cosmopolitanism. According to Anastasia Voronkova (2010), the essence of cosmopolitanism is the idea of moving beyond one's particular political, communal, territorial, cultural attachment to give allegiance to the wider human community. In particular, the concern for society globally by opposing individual selfishness over time. Therefore by facing a maturing era of globalization, cosmopolitanism has again stressed the issues regarding national borders. Easily, cosmopolitanism is the notion of increased interconnection of people on a worldwide scale, which makes the boundaries of political ethics associated with the state produce a problem of its own.

Cosmopolitanism could be understood in two different ideas. On one hand, it would build institutions and values that are not embedded in national society. Cosmopolitanism is often regarded as a selfish effort to care for the nation, without any concern for entities outside the territory of a country. On the other hand, nationalism, which is focused on achieving national interests, is also often seen as a trigger for war. Fundamentally, the issue of peace under cosmopolitan ideals, namely regarding human rights, believes that moral differences is not a notion to be questioned. Cosmopolitan believe that this understanding derives from the essence of human beings as social beings that can peacefully socialize with each other.

The political agenda desired by the Hippie Movement is to structurally change the political and social order of the United 
States, with a further political stage of the movement, which is to stop the involvement of the United States in the Cold War (especially the open war with Vietnam) and win a president later. The value of the hippie movement is inversely proportional to the direction of policy and political attitudes shown by Lyndon Baines Johnson (the then American president), as well as the contents of the Hubert Humphrey and George Wallace campaign as two presidential candidates who will advance in the political year 1968. The value of the Hippie Movement, while mushrooming in the United States, was able to change people's perceptions at the time. Public skepticism toward Humphrey and Wallace, which tended to be conservative and populist (Humphrey, who tended to ignore the issue of war and Wallace, who was pro-segregation of races), triggered a significant decrease in both electability.

This was allegedly captured as a trigger for the encouragement of the baby boomer generation that developed at that time as a voter with a relatively large quantity. Through this movement too, many terms have been introduced as the causality of the movement, both of which the only impact socially and even politically. Socially, ordinary people recognize this movement and its hooks as flower generations. Politically, this movement initiated the Silent Majority, a term introduced by Richard Nixon in the campaign as self-identification against the anti-war movement in 1969 (Pruitt 2017).

\section{Achievement Targets}

The existence of the Hippie Movement in the United States includes several achievements including peace and anti-war and environmental issues. Not only on the issue of anti-war, the Hippies gives a self-conscious effort to civil society raise awareness regarding the impact of war, especially on the environment. A social revolution that needs to be highlighted for the existence of the hippies culture is its involvement on the first Earth Day on April 22nd, 1970, with international environmental NGOs, such as Greenpeace, Sea Shepherd, and Earth First! (Miller 1991, p. 116). Hippies are fully responsible for the widespread awareness of environmental threats; of course, their role in sounding environmental degradation alarms is important besides world security for the existence of war.

The political achievements that were achieved through the encouragement of this movement were the election of Richard Nixon to outperform other candidates. Not only that but also succeeding in turning off populist and conservative politics, which began to flourish 
again in several regions of the United States at that time. Although the election of Nixon did not immediately stop the war in Vietnam. Nixon gradually use his strategy to reduce US direct involvement in the Vietnam War, until the United States officially withdrew from the Vietnam War in 1973 (Prentice 2015, p. 446). Although it could not be considered a direct involvement of the movement hippies in the policymaking process, the long journey of this movement and its effect to pressure the United States, both inside and outside the practical political stage, cannot be denied.

If drawn in the course of its history, this movement was started by a group of young men and artists on the West Coast in California. Its characteristics such as dressing in colors, going out of the house, encouraging homosexual rights, rejecting materialistic lifestyles, and using herbs and greenery for their food. Unfortunately, this movement is often only known for peacemaking with anti-war campaigns and environmental issues, even though there are many agendas they try to aim. Its success on the anti-war campaign, then conceal other attempts and successes of the movement.

\section{Organizing Strategy}

As is the case with other social movements, the anti-war movement was campaigned and spread by the Hippies. Through workers and connoisseurs of art, which uses music as a medium to convey their aspirations for the importance of an emphasis on the state concerning human security. Not only music, other aspects of art are also noted, namely regarding painting and fashion. The form of appearance is one of criticism of order and self-freedom. The organizing strategy carried out from movements, such as the Punk Culture that emerged in England against the monarchical system of government, which had a bad impact on society.

In addition, punk emerged because the economy in Britain at that time was in bad condition and the unemployment rate was at an alltime high. British youth are angry, rebellious, and do not have any job. It can be admitted that the punk culture movement is very influential for the social order, which is often interpreted as freedom and antirestraint. Essentially, what distinguishes the Hippie Movement from Punk's is that they stressed the idea peace and non-violence.

The question of the organizing strategy of this movement is not rigid, because the social system that existed in the United States at that time formed organically. Quoting from Michael Parenti (2001) in "Against Empire", he illustrates the situation in the United States 
with its many large houses glittering overlooking the vast expanse of shanty towns, where humanity is desperate and demoralized by drugs, television, and the armed forces. Seeing from Parenti's portrayal, mass communication through the media, especially television and print media, is an important matter of how this movement can become the attention of youth in the United States to fight for. Thus, indirectly formed a sense of empathy for young people and manifested into a collective identity.

As it is known that in fact in the United States in the years 19601970, there were many humanitarian problems present. One major example is the assassination of Martin Luther King as a symbol of equality in the United States. The struggle that was initiated by Dr. King ended with the signing of the Voting Right Act of 1965, which ultimately changed the various arrangements in United States on a massive and sustainable basis for people who were a minority, especially Afro-Americans. This is one of the reasons that the massive anti-war movement through Hippies culture continues to grow to express anger towards the State. When the government began to react more violently to any disagreement among its citizens with an equal increase in hippie protests, especially interventions against Hippies culture, it caused a backlash that posed a threat to the government. Towards the end of 1970 , one could see the beginning of a compromise between the counter-culture revolutionaries and the conservative government.

\section{Movement Strategy with Music as a Catalyst}

Music, like other works of art, regardless of quality, has carried out its function as a time freezer and everything in it. Eyerman (2002, p. 447) states that a song can objectify itself a movement and its history, therefore enabling to continue to be heard for the generations to come. We agree with these factors, considering music or even other works of art, could which successfully become a time freezer and used as a reference in another time and guide the audience at one time as if the consumer is approaching those frozen moments. Music as part of a study of art is indeed laden with fictitious things and metaphors, because it is commonly used to give an injection of energy in writing titles and song lyrics. However, if examined through another point of view, music is able to present other aspects of visualization and auditory of what may have happened at the time the music was produced. Even though, this understanding couldn't be applied to all types and each type of music, because it's not possible for all music to present the same thing. 
Besides having a function as a "time-freezer", music also has another function, namely as an imaginary media to transfer the message the composer trying to get across to the listener. An imagination that is channeled is not merely to lead the audience to be swayed or even fly away, but to be an alternative medium for criticism and its tendencies. It is also important to note the possibility for music to be used as a media transfer of ideas of a musician, as well as in mobilizing the masses who agree with them to be a rebel to an era. This statement is stressed by Eyerman (2002, p. 447), believing that music has the ability to articulate and fuse a group. Educative aspects such as these are slowly fading, so that idealism and ideas in music are often eliminated by the loud stage and the industrialization of music, or even more ironically labeled as a tragedy to be marginalized from the pockets of society.

Music, then, become the strategy used by this movement to develop even rapidly, especially by networking through the media of rock music and rock and roll. It was inseparable from the ethics of both music. Rock and roll is an integral part of counter-culture such as drugs and sex, whereas the presence rock music is able to affect generations both physically and emotionally. Hippies live and believe that it is the most important form of music in this movement. Rock music is revolutionary, even though there is no consensus about what that means, but for some people, that means that rock can be used by political revolutionaries in the same way as country and western music has long been used in political demonstrations by conservative neo-populists, especially in the Southern United States.

The anti-war movement initiated by the Hippies has deep implications in the music industry. One of the most iconic moments ever was Woodstock Festival in the late 6os. This festival not only stressed the idea of music, but also a purpose namely to express unrest through anti-war movements. The existence of this festival is the most successful strategy in which the hippies culture can be recognized globally.

As we discussed earlier, cultural globalization with the support of mass communication causes this movement to be reckoned with because it has influenced the socio-political system in the United States and other countries. In addition, the Woodstock Festival for hippies is a means of expressing systemic and cultural issues in society, which include natural disasters, political events, religious experiences, communal solidarity, the peak of passive consumerism, and America's first drug-free region (Miller 1991, p. 49). Precisely 
in 1967, marked the peak of the hippie's movement. At that time, a social phenomenon occurred in The Summer of Love, where thousands of hippies, majority of them are teenager that are school dropouts. They gathered in Haight Ashbury, San Francisco, United States and proceeded to listen to music, have sex, and use narcotics. The Great Woodstock Music Festival in Middlefield, Connecticut, United States, in 1969, then became the culmination of a hippies cultural celebration (Hutari 2018).

The music industry in the 60s to 70 s was significantly developing, which then become interesting to understand how this movement could develop rapidly due to the influence of world musicians who affirmed the movement brought by the Hippies. The Woodstock festival as a celebration of the hippies, then became a great achievement of this culture. Hippies were born as a form of resistance to the government and the conditions at that time. With long hair down, colorful clothes, carrying lots of love and freedom, hippies came to promote peace. They considered and believed that the Vietnam War was the fall of US democracy (CNN Indonesia 2019). The involvement of many musicians to spread the values of hippies globally has made history in a global society, not to mention the globalization of culture that gave birth to published analog productions worldwide.

Song is a medium to convey aspirations and messages and ideas, in which will create a meaning for the listener. Gradually, a song created with an emotional condition can influence the growth of a social movement's network through the hippie phenomenon. We could understand that the hippies used music and as a basis for recruitment and to achieve support (Eyerman 2002, p. 447). It will also gradually become a popular culture in the 6os to 70s. Not only because of commercial interests alone, but also because of musicians pay special attention especially to the spectrum of peace, anti-war and anti-violence.

An interesting facts from the holding of the Woodstock Festival, was John Lennon's inability to participate. Lennon, then, was an icon of the hippie's movement to counter the sub-culture present in the United States. The songwriter of "Imagine" did not participate due to the intervention of President Nixon. John Lennon, who is an antiwar activist, is considered dangerous for security as well as a threat to the country's agenda (Wildes 2017). The song written by John Lennon with the title "Imagine" is certainly closely related to the eternal cosmopolitanism ideology. 
Although the absence of John Lennon, who was role model for anti-war movements is very necessary, this gives space for another musician to rise. One of them are Jimi Hendrix, who was considered as a prophet in the field of Rock music or psychedelics and even other types of music. The Hippies are no exception, they also treated Hendrix the same. The magnum opus of Jimi Hendrix, entitled Purple Haze, criticized the government for greed in achieving hegemony in international politics. In his career before becoming a great musician, Jimi Hendrix was a conscript who was assigned during the Vietnam War. Hendrix believes that the war was only a means of satisfying state power. After expelled from the military, Hendrix intends to pursue being a musician, especially through some of his work that provides the conditions of war. Through the Purple Haze, song fans and critics have for years tried to decipher the meaning of the song in the verse "is it tomorrow, or just the end of time?", which Hendrix was trying to story tell the ferocity of war.

\section{Conclusion}

The anti-war movement initiated by the Hippies stressed the idea that social movements based on collective substantial problems would fill these mediums. Social movements that also uphold collectivity, are expected to be able to manipulate the times for mainstream narratives that are not linear with practice in the field and the need for alternative narratives to be healthy comparisons. Not only that, but also as a reminder to state authorities that community movements collectively have power which cannot be underestimated by the authority of a country of class. People's power needs to be considered for the country's selfishness.

In its development, the discourse about hippie culture stressed the importance of these three important typologies, namely mass communication, cultural globalization, and cosmopolitanism. Hippies subculture rose to become one of the global cultures because the globalization of culture makes the values of interest generation integrated with local culture in every part of the world. The approach used to do it is through art, one of which uses music as a medium for reading social phenomena more aesthetically to the public at large, an important concern in organizing and networking strategies. However, discussing existence, there is an essential question of this movement after the end of the Vietnam War, which tends to the commodification of culture that is narrow on the type of music and fashion that is gradually fading away. Nevertheless, it should be noted that the existence of this movement has had a major influence on the 
epistemology of the global social and political movements. As well as being an important trigger in the discourse of social movements with the principle of world peace. 


\section{Bibliography}

\section{Books}

Castells, M., 2010. The Rise of Network Society, Vol. 1 of the Information Age: Economy Society and Culture (2nd Edition). Sussex: John Wiley \& Sons Ltd.

Donk, W. V. D., Loader, B. D., and Nixon, P.G., 2004. Cyberprotest: New Media, Citizens and Social Movement. London: Routledge

Held, D., McGrew, A., Goldblatt, D., and Perraton, J., 1999. "Globalization, Culture, and the Fate of Nations", in David Held, Anthony McGrew, David Goldblatt, and Jonathan Perraton (eds.), Global Transformations. Stanford: Stanford University Press.

Macfarlane, S., 2007. The Hippie Narrative A Literary Perspective on the Counterculture. Jefferson: McFarland \& Company, Inc., Publishers.

McQuail, D., 2010. Mass Communication Theory (6 $6^{\text {th }}$ Edition). London: Sage Publications.

Miller, T., 1991. The Hippies And American Values $2^{\text {nd }}$ Edition. Knoxville: The University of Tennessee Press.

Parenti, M., 2001. Against Empire. San Francisco: City Lights Publisher.

\section{Journal}

Buechler, S. M., 1995. "New Social Movement Theories", The Sociological Quarterly, Vol. 36, No. 3, pp. 441-464.

Buttgieg, J. A., 2005. "The Contemporary Discourse on Civil Society: A Gramscian Critique”, Boundary 2, 32(1), pp. 33-52.

Eyerman, R., 2002. "Music in Movement: Cultural Politics and Old and New Social Movements", Qualitative Sociology, Vol. 25, No. 3, pp. 443-458.

Das, M., 1981. "Social Movements, Social Change and Mass 
Communication", International Review of Modern Sociology, Vol. 11 (Jan-Des 1981). pp. 127-143.

Poster, M., 2008. "Global Media and Culture", New Literary History, 39(3), pp. 685-703.

Prentice, D. L., 2015. "Choosing "the Long Road": Henry Kissinger, Melvin Laird, Vietnamization, and the War over Nixon's Vietnam Strategy", Diplomatic History, Vol. 40 No. 3. pp. 445-474.

\section{Online Article}

CNN Indonesia., 2019. "Woodstock 1969: Festival Musik yang Mengubah Amerika”, CNN Indonesia, August 16th, 2019 [online]. Retrieved from https://www.cnnindonesia.com/ hiburan/20190816093616-227-421856/woodstock-1969festival-musik-yang-mengubah-amerika (accessed on October 17th, 2019).

Hutari, F., 2018. "Virus Kaum Hippies", Historia, April 28th, 2018 [online]. Retrieved from https://historia.id/kultur/articles/ virus-kaum-hippies-PKkgQ (accessed on October 16th, 2019).

Manaev, G., and O'Callaghan, T., 2018. "Bagaimana Kaum Hippie Datang ke Uni Soviet?”, Russia Beyond, June 19th, 2018 [online]. Retrieved from https://id.rbth.com/sejarah/80279komunitas-hippie-soviet-fyx (accessed on October 15th, 2019).

Pruitt, S., 2018. "How the Vietnam War Empowered the Hippie Movement", History.com, September 14th, 2018 [online]. Retrieved from https://www.history.com/news/vietnamwar-hippies-counter-culture (accessed on October 15th, 2019).

Voronkova, A., 2010. "Are nationalism and cosmopolitanism compatible?”, E-International Relation, November 25th, 2010 [online]. Retrieved from https://www.e-ir. info/2010/11/25/are-nationalism-and-cosmopolitanismcompatible/ (accessed on October 16th, 2019). 
Wibisono, N., 2017. "Nostalgia Kejayaan Generasi Bunga”, Tirto. id, August 11th, 2017 [online]. Retrieved from https://tirto. id/nostalgia-kejayaan-generasi-bunga-cumc (accessed on October 16th, 2019).

Wildes, L., 2017. "Nixon Administration Targets John Lennon", UTNE Reader, October 2017 [online]. Retrieved from https://www.utne.com/politics/nixon-targets-john-lennonzeoz1710zols (accessed on October 16th, 2019). 